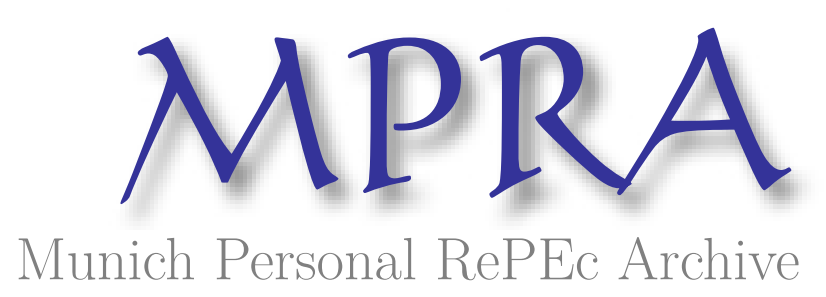

\title{
Households' willingness to pay for reliable electricity services in Ghana
}

\author{
Taale, Francis and Kyeremeh, Christian \\ Department of Economics, University of Cape Coast, Department of \\ Purchasing and Supply, Sunyani Polytechnic
}

27 July 2015

Online at https://mpra.ub.uni-muenchen.de/65780/

MPRA Paper No. 65780, posted 01 Aug 2015 08:13 UTC 


\author{
Households' willingness to pay for reliable electricity services in Ghana \\ Francis Taale $^{1}$ and Christian Kyeremeh ${ }^{2}$ \\ ${ }^{1}$ Department of Economics, University of Cape Coast, Cape Coast, Ghana, \\ ${ }^{2}$ Department of Purchasing and Supply, Sunyani Polytechnic, Sunyani, Ghana
}

\begin{abstract}
Access to reliable electricity is important in increasing the living standards of households and promoting sustainable development. However, Ghanaian households have had to grapple with frequent power outages and poor quality electricity services in recent times. This study examines the factors influencing households' willingness to pay for reliable electricity services in Ghana. Using data collected from 950 households in the Cape Coast Metropolitan Area and the tobit regression technique, it was revealed that monthly income, prior notice on power outages, business ownership, separate meter ownership, household size and education significantly affect willingness to pay for reliable electricity services. On the average, households were prepared to pay 44 percent ( $\mathrm{GH} \notin 6.8)$ more, relative to the mean monthly electricity bill in the sample, to improve electricity services. It is envisaged that the findings would be used by policy makers and utility companies to make electricity generation and distribution more sustainable and efficient.
\end{abstract}

Keywords: reliable electricity services, households, separate meter, education, willingness to pay, Ghana 


\section{Introduction}

Access to electricity is important in improving the living standards of households in developing countries. It is also crucial in enabling the countries themselves to advance economically by facilitating production. According to Louw, Conradie, Howells and Dekenah (2008), reliable electricity services allows households to meet their daily requirements of cooking, learning and entertainment. Access to quality public services including electricity is also inextricably linked to the Millennium Development Goals (World Bank, 2003). Modern forms of energy, of which electricity is part, is a prerequisite for sustainable development and overall improvement in the quality of life. Reliable electricity supply can stimulate economic growth that will have beneficial spill over effects on households living in poverty and helps to ensure environmental sustainability by cutting down the consumption of wood based fuels such as charcoal and firewood (see Kuunibe, Issahaku \& Nkegbe, 2013). Unfortunately, in many countries in Sub-Saharan Africa, electricity is not only limited in terms of access but its quality in terms of reliability is also questionable. This is fuelled, in part, by growing demand for energy, with electricity consumption estimated to grow at the rate of 2.6 percent per annum, shortage of funds to undertake investment and diversify generation (Muzenda, 2009) and partly by rapid population growth and urbanisation (Mariwah, Kendie \& Dei, 2010).

In Ghana, electricity services are marred by low generation and frequent outages, with the mean power outage estimated to be 10 hours per month (Edjekumehene \& Cobson-Cobbold, 2011). Between 2006 and 2007, for instance, the country experienced electricity crisis for 13 months (Institute of Economic Affairs, 2007). Similarly, between August 2012 and June 2013, the country had to resort to load-shedding as a result of the non-availability of natural gas to generate power from thermal plants (Energy Commission, 2013). Ghana's total population now stands at about 25 million but is estimated to reach 40 million by 2030 (United Nations, 2011). These projections have consequences for electricity demand and could worsen a potentially bad situation. As noted by Oteng-Adjei (2012), electricity generation in Ghana will need to be between 18 and 25 Giga Watts in order to meet domestic demand by the year 2030. Household demand for electricity is also estimated to reach between 7,000 and 13,000 Giga Watt hours by 2020 (Institute of Statistical, Social and Economic Research, 2005). Three things are at stake. First, electricity generation must be at a cheaper cost, competitively priced and from efficient and sustainable sources. The quality 
of supply must also be intensive, reliable and continuous. In the second instance, investment into generation must be high and must also come from a combination of sources including the private sector in order to make electricity generation and distribution more sustainable. Finally, consumers, especially domestic users, must be willing to pay extra charges in order to increase generation and improve distribution. Thus, there is the need to identify the factors underpinning willingness to pay for reliable electricity services among various categories of consumers including households at different geographical locations and socioeconomic backgrounds.

It has been reported, with varying degree of consent, in studies in other countries, that willingness to pay for electricity service reliability depends on several factors including age, sex, education, family size and composition, house ownership, household income, value orientation, political party affiliation, monthly electricity bill, and access to information on power outages (see Hobman and Frederiks, 2014; Shi, Zhou \& Kristrom, 2013; Zoric \& Hrovatin, 2012; Hansla, 2011; Kotchen \& Moore, 2007;; Rowlands, Scott \& Parker, 2003; Zarnikau, 2003; Bergstrom, Stoll \& Randall, 1989). This study employed a contingent valuation survey and Tobit regression technique that enables us to account for zero bids, to investigate the factors influencing households' willingness to pay for improved electricity services in Ghana. The rest of the paper is organised into four sections. Section two is devoted to review of related literature. The third section discusses the methodology and the empirical model. Section four presents the results and discussion and the fifth and final section concludes the study and the policy implications of the findings.

\section{Literature Review}

A number of methodological approaches have been developed to measure people's willingness to pay to ensure the sustainability of publicly funded goods and services. The contingent valuation method (CVM) is an example of the stated preference methods whereby hypothetical markets are created for a non-marketed commodity and individuals are asked to state how much they would be willing to pay for the commodity if the market really existed. It draws upon economic theory and survey research to elicit directly from consumers the values they place upon commodities or services (Carson \& Hanemann, 2005; Mitchell \& Carson, 1989). In a contingent study, the proposed improvement (or damage) in the provision of the commodity is presented in a 
hypothetical market and the individual is then asked to express his or her maximum (minimum) willingness to pay (or accept) to benefit (loose) from the consumption (destruction) of the commodity (Seip \& Strand, 1992). Contingent valuation has over seven decades of existence. Bowen (1943) and Ciriacy-Wantrup (1947) were the first to propose the use of specially structured public opinion surveys to value what Bowen (1943) called 'social goods' and Ciriacy-Wantrup (1947) referred to as 'collective, extra-market goods' that cannot easily be sold to individual consumers and the quantities available to different individuals cannot be adjusted according to their respective tastes. Both Bowen and Ciriacy-Wantrup saw that a typical feature of these goods was that, while individuals would have their own distinctive demand curves for these goods, the aggregate demand curve is obtained by adding the marginal rate of substitution (expressed in money) of the various individuals at each possible quantity of the social good.

Though Bowen (1943) and Ciriacy-Wantrup (1947) envisaged the CVM in the 1940s, empirical studies on the technique started to flourish fifty years later, particularly after the National Oceanic and Atmospheric Administration's blue-ribbon panel guidelines (Hoyos \& Mariel, 2010). In Ghana, contingent valuation has been applied to measure willingness to pay for a wide range of goods including water (Baidoo, Al-hassan, Asuming-Brempong, Osei-Akoto \& Asante, 2013), waste management (Ahiakpor, Alnaa \& Aglobitse, 2011) and biodiversity conservation (Vondolia, 2009), and it was revealed that socio-demographic factors- age, education, household size, number of dependents, gender and income- affect willingness to pay. Carlson and Martinsson (2007) and Zarnikau (2003) used a CVM to value electricity supply reliability and found that education, income, home ownership, family size and composition affect willingness to pay for reliable electricity. Aravena-Novielli, Hutchinson and Longo (2012) elicited households' willingness to pay for reliable electricity generation in Chile. Their study revealed that consumers are willing to pay more for reliable electricity supply and also have a strong preference for energy from renewable sources than from fossil fuels. Carlsson, Martinson and Akay (2009) suggested that income is a major determinant of willingness to pay for electricity services than other socioeconomic variables including age and education. In the USA, Goett, Hudson and Train (2000) found that households were willing to pay about half the price of a kilowatt-hour to reduce the number of power outages from four to two and their duration from 30 minutes to 30 seconds. Quartey (2011) imitated that the willingness to pay for electricity from alternative sources 
correlates negatively with number of dependents in a household and positively with monthly electricity bills as well as power usage.

Abdullah and Mariel (2010) studied willingness to pay for improved electricity services in Kenya and reported that household size, age, employment status, bank account holding and years of residence in the study area affect willingness to pay for reductions in power outages. Edkins (2008) reiterates the influence of income on WTP. Abdullah and Jeanty (2011) indicated that people with higher income and those with an interest in home based businesses are willing to pay more for reliable electricity services. According to Gunatilake, Maddipati and Patail (2012) households' willingness to pay for electricity services is influenced by the ownership of a home business, perceived benefits of reliable electricity, per capita household income and the number of children of school going age in the household.

A number of authors have also studied willingness to pay for electricity from renewable sources. Du Preez, Menzies, Sale and Hosking (2012) argued that age and awareness about environmental issues affect attitudes towards the demand and willingness to pay for electricity from renewable sources. Pepermans (2011) investigated the determinants of Flemish households' willingness to pay to for electricity from renewable sources and found that households were willing to pay approximately $€ 190$ per annum. Pepermans indicates that level of education, environmental awareness as well as income predict willingness to pay. Wiser (2007) used a split-sample dichotomous choice approach on 1574 respondents to explore willingness to pay for renewable energy and found that willingness to pay is higher under the collective payment format than voluntary mechanism. Private provision of electricity also attracted a higher willingness to pay than the government. The study by Wiser (2007) has brought two important policy issues to the fore. First, it demonstrates the suspicion of government's ability as a producer. It also proves that respondents are more likely to donate towards public services when they know for a fact that every user would contribute and that the funds would be used for the intended purpose.

Scarpa and Willis (2010) investigated British households' willingness to pay for renewable energy technologies and observed that though renewable energy is significantly valued by respondents, a majority of the respondents' were not prepared to pay additional charges. On the contrary, a study 
by Martinez-paz, Almansa-Saez and Pemi-Llorente (2011) revealed that over 90 percent of residents participating in the market are willing to pay extra charges to increase the amount of electricity generated from renewable sources. Martinez-paz et al (2011) also found that the average willingness to pay $(€ 16.4)$ per month per household constituted an increase of 27 percent in the average Spanish household monthly expenditure on electricity. Amador, Gonzalez and RamosReal (2012) conducted a contingent valuation on customers' preferences and willingness to pay for reliable electricity supply in the Canary Islands, Spain. Regarding the estimated WTP, they found that customers who experienced more serious outages in the past showed higher willingness to pay. Additionally, highly-educated respondents, those with concern for greenhouse gas emissions as well as customers who engage in energy saving actions at home were more willing to pay to reduce power outages.

Though CVM has gained widespread applications, unresolved concerns over its usefulness on final revealed values still remain high. Some of these concerns are worth mentioning. Hobman and Frederiks (2014), Claudy, Peterson and O’Driscoll (2012) as well as Dupont and Bateman (2012) argued that willingness to pay for electricity services reliability, and any other good of limited private nature, is often both a moral and political issue. Although, many individuals value reliable electricity supply and prefer energy from environmentally friendly sources, they are often not in the mood to display support for energy sector reforms that will increase their household charges. No matter the social environment, many households feel that they already pay higher tariffs on social utilities, of which electricity is part, and thus see no reason why they should be asked to pay more. Further, because they participate in voting for elected state officer holders, they feel it mandatory on the government to provide them with such services freely or if anything at all at reasonable rates. Hausman (2012) reports that CVM suffers three fundamental problems, hypothetical response bias, willingness to accept-willingness to pay dichotomy and embedding effect, which renders it an ineffective tool in terms of policy formulation. According to Hausman (2012), people do not do what they say. A 'yes' response to hypothetical questions, as pertains in contingent valuation studies, cannot be interpreted to mean that the respondent would do the same or even a similar in reality and neither does it communicate economic power. Mitchell and Carson (1989) also note that the interviewer-interviewee relationship can affect the reliability of the results of CVM. Another concern about CVM is information effect (Nemb \& Yah, 2010; Whitehead \& 
Blomquist, 2008; Kagel, Harstad \& Levin, 1987). Kahneman and Knetsch (1992) are of the view that the assessed value of any (public) good is arbitrary because willingness to pay for the same good can vary depending on the framing of the contingent valuation scenario. Nemb and Yah (2010), Ajzen, Brown and Rosenthal (1996), Hoevenagel and van der Linden (1993) as well as Bergstrom et al (1989) have also noted that different information packages have significant influence on willingness to pay, the number of protest bids and response rates, although Boyle (1989) found no significant impact of information and respondents' willingness to pay. Nessim and Dodge (1995) posited that expert judgments are superior to CVM because an educated guess is more often better than a random selection of a presumably adequate price from a number of price possibilities. On the contrary, Scholderer, Balderjahn, Bredahl and Grunert (1999) labelled expert judgments as a poor measurement instrument with low validity. Whittington (2004) and Carson et al (2001) report that many of the alleged problems with CVM can be resolved by careful study design and implementation, and that the results of the CVM technique is reliable and informative in eliciting passive or bequest values-an aspect of value often neglected in expert judgements. For example, a person may be willing to pay for reliable electricity services not merely because he himself expects to benefit directly but because he deems it morally fit to ensure that others would be able to have access to better services.

\section{Methodology}

\section{Study Area}

The study was conducted in the Cape Coast Metropolitan Area. The total population of the area is 169,894 , comprising 82,810 males and 87,084 females. The metropolis is inhabited by a total of 40,145 households, with an average household size of 3.5 (Ghana Statistical Service, 2013). The average annual household income in the metropolis is about GH $₫ 650.00$ (Cape Coast Metropolitan Assembly, 2009). Trading is the dominant form of economic activity in the Cape Coast Metropolitan Area (Boohene \& Peprah, 2012). Over 80 percent of the inhabitants have access to electricity, and out of this number, nearly 65 percent use prepaid meters (Electricity Company of Ghana, 2013). 


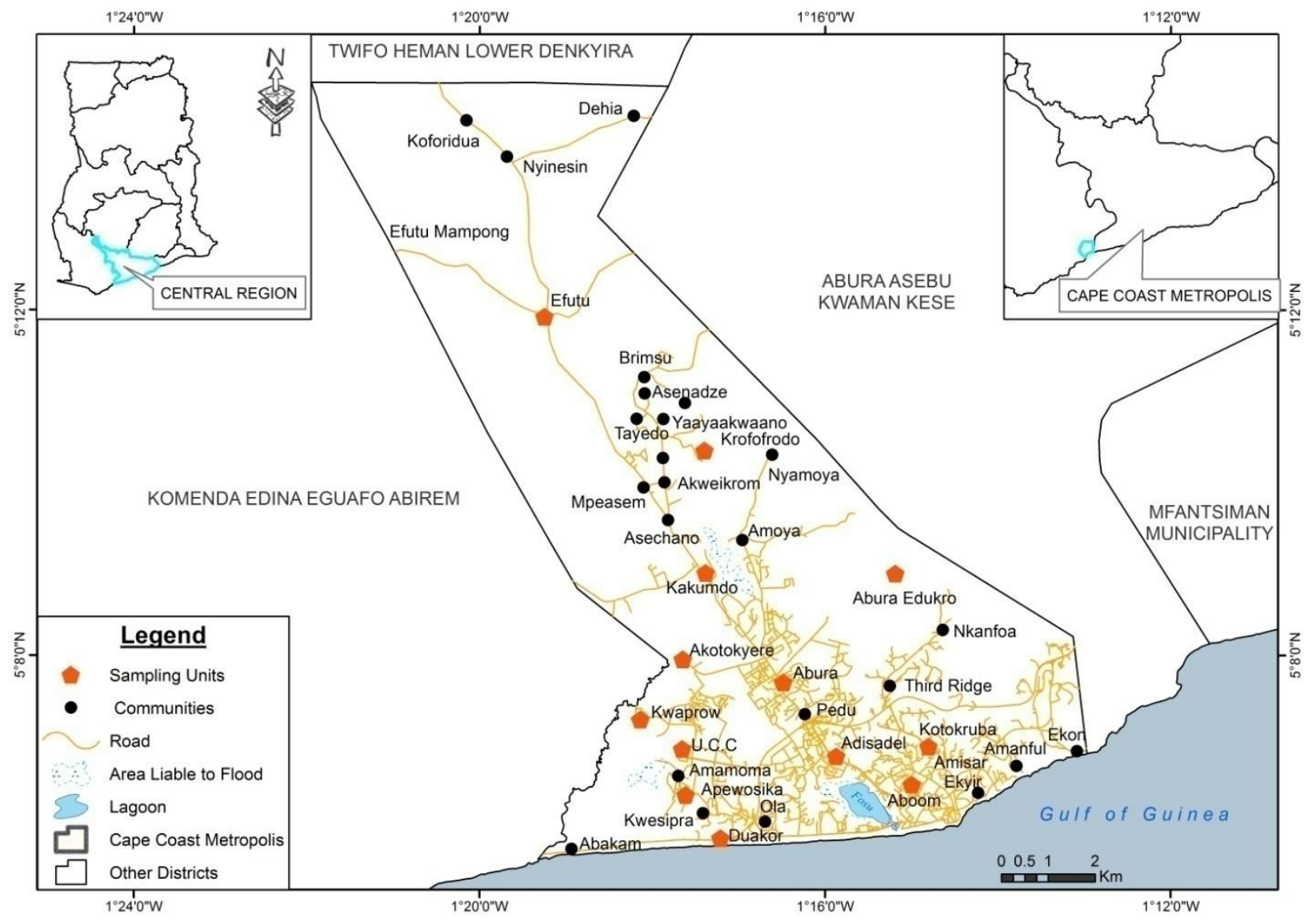

Figure 1: A map of Cape Coast Metropolitan Area showing the location of survey respondents

\section{Study Design and Implementation}

The study used primary data collected from 950 households randomly selected from 13 communities (see Map above). The basic data collection instrument utilized was an interview schedule. We chose this method because we envisaged that most of our respondents could not read and write in English Language. Further, by administering the instrument in the local dialects, (Fante, Twi and Ewe), we were able to ask more probing questions and to detect and remove warmglow giving (Andreoni, 1990). It also improved the response rate and gave us an opportunity to complete the data collection on time. Some responses (about 5 percent of the total sample) were gathered using the questionnaire method to enable us avoid the interviewer-interviewee bias (Mitchell \& Carson, 1989). Household heads were the primary respondents but in some cases we interviewed any other person 20 years and above in the absence of the household head. The data 
collection commenced at the middle of May 2013 and ended in June 2013. STATA version 12.0 was used to process the data.

\section{The Theoretical and Empirical Model}

The paper is based on the random utility theory. Suppose an electricity user is told that electricity supply reliability will improve from a given level of $\mathrm{E}^{0}$ to $\mathrm{E}^{*}$, and that the improvement will cost him or her $\mathbb{C W}$. The respondent is faced with the decision whether to accept to pay or not to pay. The individual's utility function is given as:

$U=U\left(X_{1}, X_{2}\right)$

Where $X_{1}$ represents electricity usage and $X_{2}$ stands for other composite goods. The utility function is known with certainty to the respondent but it is not directly observable to the researcher. This can be represented as: $U_{i}=V_{i}+\varepsilon_{i}$

Where $U_{i}$ is the utility from alternative $i, V_{i}$ is the observable component and $\varepsilon_{i}$ is the random

component. The respondent will be willing to pay for improved electricity services if the satisfaction from accessing it is at least equal to the satisfaction under the current supply conditions. This is specified as follows:

$v_{1}\left(p_{1}, p_{2}, M-W T P\right) \geq v_{0}\left(p_{1}, p_{2}, M\right)$

Where WTP is the willingness to pay, $\mathrm{M}$ represents income, $p_{1}$ and $p_{2}$ denote the prices of electricity and composite goods respectively.

\section{The Tobit Model}

This study uses the Tobit model (Tobin, 1958) to identify the determinants of willingness to pay for reliable electricity services. Following Greene (2003), the model is expressed as:

$W T P_{i}=X_{i} \beta+\mu_{i}, \quad$ if $X_{i} \beta+\mu_{i}>0$

$W T P_{i}=0, \quad$ if $X_{i} \beta+\mu_{i} \leq 0$ 
Where $X_{i}$ is a set of explanatory variables of the ith respondent, $u_{i}$ is the random error term assumed to be independent and normally distributed across households, and $\beta$ is a vector of parameters.

For an observation drawn at random, the expected WTP is given by:

$$
E\left(W T P_{i}\right)=\Phi\left(X_{i} \beta / \sigma\right)\left(X_{i} \beta+\sigma \lambda_{i}\right) ; \quad \lambda_{i}=\phi\left(X_{i} \beta / \sigma\right) / \Phi\left(X_{i} \beta / \sigma\right)
$$

In equation (4), $\Phi$ stands for the normal distribution function, $\lambda$ represents the normal density function and $\sigma$ is the standard deviation. Ameniya (1973) demonstrates that the expected value of WTP for observations above zero, denoted as $E\left(W T P^{*}\right)$, is simply $X \beta$ plus the expected value of the truncated normal error term. This is expressed as:

$E\left(W T P_{i}\right)=\Phi\left({ }^{X_{i} \beta} / \sigma\right) E\left(W T P^{*}\right)$

Unlike in linear models, the marginal effect for a given explanatory variable in the Tobit-type estimations is nonlinear and thus not equal to the $\beta_{i}$. A useful decomposition of the marginal effect proposed by McDonald and Moffitt (1980) can be written as:

$\left.\partial E\left(W T P_{i}\right) / \partial X_{i}=\Phi\left(X_{i} \beta / \sigma\right)\left({ }^{\partial E(W T P *}\right) / \partial X_{i}\right)+E\left(W T P^{*}\right)\left({ }^{\partial \Phi\left({ }^{\left({ }_{i} \beta\right.} / \sigma\right)} / \partial X_{i}\right)$

Assuming that the censoring point is zero, the empirical model for the study can be written as follows:

$$
\begin{aligned}
& W T P=\alpha+\beta_{1} \text { Age }+\beta_{2} \text { Sex }+\beta_{3} E d u+\beta_{4} M S+\beta_{5} \text { Hsize }+\beta_{6} \text { Trad } \\
& +\beta_{7} \text { Inc }+\beta_{8} \text { Hown }+\beta_{9} P P O+\beta_{10} M E+\beta_{11} S M+\beta_{12} P R N+\varepsilon \text { if WTP* }>0 \\
& =0 \text { if WTP* } \leq 0
\end{aligned}
$$

The definition, measurement and a priori signs of the variables used in equation (7) are illustrated in Table 1. 
Table 1: Definition and measurement of variables

\begin{tabular}{|c|c|c|c|}
\hline Variable & Definition & Measurement & $\begin{array}{l}\text { Expected } \\
\text { sign }\end{array}$ \\
\hline WTP & Willingness to pay & Amount in Ghana Cedis & \\
\hline Age & Age of respondent & Number of years & $+/-$ \\
\hline Sex & Sex of respondent & Male $=1$, Female $=0$ & + \\
\hline Edu & Education of respondent & $\begin{array}{l}\text { High school =1, No High school } \\
=0\end{array}$ & + \\
\hline MS & Marital status of respondent & Married $=1$, Otherwise $=0$ & + \\
\hline Hsize & Household size & Number of people & - \\
\hline Trad & Trader & Trader $=1$, Otherwise $=0$ & + \\
\hline Inc & Household monthly income & Amount in Ghana Cedis & + \\
\hline Hown & House ownership & Self-owned $=1$, Otherwise $=0$ & + \\
\hline PPO & Previous power outages & Number of hours & + \\
\hline ME & $\begin{array}{l}\text { Monthly expenditure } \\
\text { electricity }\end{array}$ & Amount in Ghana Cedis & + \\
\hline SM & Separate Meter & Separate meter $=1$, Otherwise $=0$ & + \\
\hline PRN & Prior notice on outages & Prior notice $=1$, Otherwise $=0$ & - \\
\hline
\end{tabular}

\section{Results and Discussion}

The focus of the study was to examine households' willingness to pay for reliable electricity services. Descriptive statistics of the findings are presented in Table 2. The least ages of the respondents ranged between 20 and 85 years, with a mean age of about 39 years. Males (54\%) were dominant compared to females. Average income of the sampled respondents was $\mathrm{GH} \phi 397.71$. The monthly expenditure on electricity ranged from $\mathrm{GH} \phi 4$ to $\mathrm{GH} \phi 60$. Trading was the dominant form $(63 \%)$ of employment. The average household size was 4.05 . The largest household was made up 10 members. About 58 percent of the respondents lived in their own apartments. The highest form of education for about 25 percent of the respondents was junior high 
school. About 26 percent of the respondents had senior high education, 21 percent had tertiary level education whereas 28 percent had no formal education.

Table 2: Descriptive statistics of variables used in the model

\begin{tabular}{lllll}
\hline Variables & Mean & Stand. Dev. & Min. & Max. \\
\hline WTP & 6.8032 & 7.7442 & 0 & 50 \\
Age & 38.9790 & 11.2721 & 20 & 85 \\
Married & 0.6116 & 0.4876 & 0 & 1 \\
Sex & 0.5126 & 0.5001 & 0 & 1 \\
Household size & 4.0516 & 1.7638 & 1 & 10 \\
Monthly Income & 397.7146 & 334.4960 & 100 & 2500 \\
Education & 0.4579 & 0.4985 & 0 & 1 \\
Trader & 0.2916 & 0.4547 & 0 & 1 \\
House ownership & 0.3842 & 0.4866 & 0 & 1 \\
Separate meter & 0.2852 & 0.4518 & 0 & 1 \\
Duration of power outage & 4.7928 & 3.0116 & 0.50 & 24 \\
Monthly expenditure on electricity & 15.5206 & 9.1352 & 4 & 60 \\
Prior notice on outages & 0.1305 & 0.3371 & 0 & 1 \\
Sample Size & 950 & & & \\
\hline
\end{tabular}

Households with separate electricity meters were the minority $(38.7 \%)$ compared to those that shared $(61.3 \%)$ electricity meter. The average willingness to pay is approximately GH $₫ 6.80$. Assuming that the sample mean WTP is representative of the metropolis and country. We calculate the aggregate WTP for the CCMA and the country by multiplying the mean WTP by the total number of households in each case. Given the current population of the metropolis of 169,894, with an average household size of 4.05, the number of households will be 41,949 and with a population of 24,658,823, the total number of households for Ghana will be 6,088,598. Multiplying these by the mean WTP, the aggregate WTP for the metropolis and the country will be $\mathrm{GH} \notin 285253.20$ and $\mathrm{GH} ф 41402466.40$ respectively. In terms of tariff adjustment, the mean WTP $(\mathrm{GH} \not 6.80)$ represents about 44 percent increase in the average monthly expenditure on electricity. 
The estimated results as presented in Table 3 indicate that most of the explanatory variables included in the model are statistically significant and have the expected signs. Age, sex, house ownership and monthly expenditure on electricity are insignificant although they had the expected signs. The coefficient of monthly income is positive and statistically significant at 1 percent. This implies that willingness to pay for improved electricity services increases with income. Income is, generally, an indicator of purchasing power. Higher income households have higher purchasing power and therefore can afford to pay extra for improvements in electricity service. The ability of income to positively influence willingness to pay, as depicted by the outcome of this study, is consistent with literature. Several studies have found a direct relationship between income and willingness to pay. Abdullah and Jeanty (2011), Abdullah and Mariel (2010) as well as Edkins (2008) all posit a direct relationship between income and willingness to pay for reliable electricity. The Australian Energy Market Commission (2012) indicates that wealthy households allocate their financial resources for quality and reliable services including electricity. Although such households, all other things being equal, are in a better position to deal with power outages compared to poorer households, they are often more inclined to pay for uninterrupted power from the national grid even at higher prices.

Household size is negatively associated with willingness to pay for improved electricity service and it is statistically significant at five percent. The results show that an additional household member decreases the willingness to pay by 22.4 percent. The possible reason for the negative relationship between household size and willingness to pay is that higher household size comes with it the attendant cost of providing for the basic needs of the members and as such paying for improvement in electricity may not be an immediate priority. In Ghana, like most sub-Saharan African countries, the need to provide food, clothing, accommodation, school fees and health care for dependents is already a burden for households with many members. Faced with rising cost of living and fewer earning opportunities, household heads with many dependents may not have the necessary financial resources to enable them to pay extra charges for improvement in electricity service. This is in line with Maslow's (1943) basic human needs theory. As posited by Streeten, Burki, ul Haq, Hicks and Stewart (1981), poor households do not worry much about the quality of public services more than they care about their immediate needs-food, clothing or shelter. The negative impact of household size on willingness to pay in this study is contrary to the work by Abdullah and Marriel (2010) and Gunatilake et al (2012) who found a positive relationship 
between household size and willingness to pay for improved electricity services. However, it is in line with the findings of Akcura (2011), Quartey (2011) and Bigerna and Polinori (2011). The implication of this finding is that reducing household size will ease the burden on household heads and allow them the economic space to contribute for the improvement of electricity services.

Table 3: Estimated results of the regression

\begin{tabular}{llll}
\hline Variable & Coefficient & Stand. Error & $\begin{array}{l}\text { Marginal } \\
\text { effect }\end{array}$ \\
\hline Constant & $4.4569^{* * *}$ & 1.5829 & \\
Age & -0.0348 & 0.0320 & -0.0191 \\
Married & $1.4108^{* *}$ & 0.7112 & 0.7254 \\
Sex & 0.8302 & 0.7384 & 0.4308 \\
Household size & $-0.4494^{* *}$ & 0.2005 & -0.2243 \\
Monthly Income & $0.5498^{* * *}$ & 0.1437 & 0.2744 \\
Education & $0.4976^{* * *}$ & 0.0432 & 0.2552 \\
Trader & $1.7759^{* *}$ & 0.8253 & 0.8863 \\
House ownership & 0.6246 & 0.7440 & 0.2459 \\
Separate meter & $0.8151^{* * *}$ & 0.1140 & 0.4181 \\
Duration of power outage & $0.7839^{* * *}$ & 0.1181 & 0.4030 \\
Monthly expenditure on electricity & -0.0079 & 0.0419 & -0.0041 \\
Prior Notice on outages & $2.4887 * * *$ & 0.9555 & 1.2421 \\
Log Likelihood & -2549.4743 & & \\
LR $\chi^{2}(12)$ & 81.26 & & \\
Pseudo $R^{2}$ & 0.2157 & & \\
$\mathrm{~N}$ & 945 & & \\
\hline$* * *$ and ** indicate relevant variables are statistically significant at $1 \%$ and $5 \%$ levels respectively.
\end{tabular}

Education of the household head is another socio-demographic factor included in the model. The dummy created for education is significant and shows the expected sign. The results show that people with at least secondary education are likely to pay for improved electricity services than those without high school education. Generally, higher education increases an individual's 
probability of being employed in a white-collar job. People employed in such jobs tend to own and rely on electrical appliances for their personal and professional needs compared to those with lower education and fewer home appliances (Abdullah \& Jeanty, 2011). Being a trader increases willingness to pay for improved electricity supply. Most traders, especially market women, do not have the luxury of time to cook every day and because they usually return home late they are motivated to have uninterrupted power supply so that they can prepare food in bulk and preserve it. Similarly, dealers of frozen foods and other perishable goods need constant supply of power for their activities. The results suggest that enhancing trading activities could go a long way to improve willingness to pay for electricity supply.

The study also sought to find out the effect of households' past power outage experience on their willingness to pay to improve electricity supply. As envisaged, households that experienced power outage lasting several hours in the week preceding the study were willing to pay to reduce the frequency of power outages. The coefficient of duration of power outage is positive and significant at one percent. This implies that an additional hour of power outage in the previous period results in 40.30 percent increase in the willingness to pay for reliable electricity supply. This is because power outages, especially those that last for long hours or occur unexpectedly, are unpleasant and most households would pay to avoid the negative experience associated with it. This finding is not unique. In a study among Swedish households, Carlsson and Martinsson (2008) found a positive relationship between duration of power outage and willingness to pay for improved electricity services. Similarly, Otegbulu (2011) discovered that most households in Nigeria, regardless of socioeconomic backgrounds, cherish reliable power supply and are willing to pay extra tariff to access it.

Table 3 further reveals that prior notice on outages is positively associated with willingness to pay. Prior notice is statistically significant in explaining willingness to pay at 1 percent level of significance. Households attach importance to being adequately informed of any power outages. Marital status is positive and significant at 5 percent indicating that being married increases the willingness to pay by about 72.54 percent.

The status of the meter used by the household is important in analysing the decision of households to pay for improvement in electricity service. The meter may be separately owned or shared. The coefficient of separate meter is statistically significant at 1 percent and has the expected sign. 
People who use separate meters are inclined to pay more for improvement in electricity supply than those sharing meters. A plausible explanation is that having a separate meter solves part of the challenges related to free-riding. When an electricity meter is shared among households, they are exposed to the trauma related to other households not declaring their full consumption. Some households may buy and use indoor appliances such as kettles, dryers, electric irons and ovens without the knowledge of those with whom they share the meter and contribute toward the payments for the electricity. In such situations, those households that declare their full consumption would end up paying more. However, having a separate meter solves this problem and increases the households' confidence that the benefits associated with improved electricity services would accrue fully to them. This findings call for the need to provide households with separate meters as much as possible.

From Table 4, it can be observed that 244 households were not willing to pay to improve electricity service. Over 26 percent of respondents in this category felt that the current electricity tariff was already too high. This is followed by inability to pay extra amount for electricity (21.3\%). About 16 percent of the respondents were of the views that government should provide funds for the improvement. Looking at the reasons given by the respondents, policy makers and electricity companies need to understand that domestic users of electricity services have valid concerns about electricity generation and distribution which must first be addressed before they can be convinced to pay more for service improvement. In particular, state functionaries need to build trust and confidence among the general public in relation to the management of public funds.

Lack of trust and confidence in public institutions has been cited as one of the major issues that can quell the enthusiasm of the 'ordinary' citizens and subsequently fuel their refusal to accept more responsibilities towards improving the quality of public services (Asante, 2013). About 18 percent of the respondents indicated that they would only be willing to pay extra charges if they see improvement in electricity supply and receive information on a regular basis about power outages to enable them plan ahead. According to the Centre for Environment and Development (2003, cited in Mariwah et al, 2010), unreliable service, which does not arrive in time or is not carried out according to promise and the expectations of the people has consequences for trust and the peoples' willingness to pay. Similarly, Whittington (2004) is of the view that the integrity of public institutions or affiliate organizations that collect and manage public monies is a critical 
factor in willingness to pay. When people, especially in low income groups, are convinced beyond reasonable doubt that the financial contributions they make will be used for the intended purposes, they are less likely to resist paying more for public services. In contrast, when they do not trust the managing institution, persons or entities involved in the administration of the finances then it will be a daunting task asking them to pay more.

Table 4: Reasons for not willing to pay for reliable electricity supply

\begin{tabular}{lll}
\hline Reason & Frequency & Percentage \\
\hline The electricity tariff is already too high & 64 & 26.2 \\
I do not have enough income to pay for reliable electricity & 52 & 21.3 \\
services & & \\
I want to see improvement in electricity supply before I can & & \\
pay more charges & 45 & 18.4 \\
Government should provide funds for the improvement & 38 & 15.6 \\
I do not trust the extra money will be used for the intended & 18 & 7.4 \\
purpose & & \\
There are more pressing use of the extra income to my & & 4.9 \\
household than reliable electricity supply & 12 & 4.1 \\
The electricity companies should bear the extra cost & 10 & 2.0 \\
No response & 5 & $99.9^{*}$ \\
\hline Total & 244 &
\end{tabular}

*Percentages may not add up to 100 because of rounding problems.

In an environment of unstable electricity supply, households constantly need to look for alternative sources of energy. Table 5 presents information on the alternative sources of lighting respondents used during power outages. About 30 percent used torch or battery powered lamps to provide light for their households whenever power outages occur. This is the highest form of mitigation for power outages in the sample of respondents that participated in the study. The next most used alternative source of light was candle (25.1\%). Although candle is not used by majority of the respondents, the fact that it is the second most used alternative still raises concern and the need for grid power to be made efficient and available at all times. 
Table 5: Alternative sources of light used by respondents during power outages

\begin{tabular}{lll}
\hline Type of alternative source & Frequency & Percentage \\
\hline Torch/Battery Lamp & 286 & 30.1 \\
Candle & 238 & 25.1 \\
Mobile phone & 185 & 19.5 \\
Rechargeable Electric Lamp & 141 & 14.8 \\
Lantern & 74 & 7.8 \\
Standby Generator & 6 & 0.6 \\
Solar Lamp & 4 & 0.4 \\
No response & 16 & 1.7 \\
\hline Total & 950 & 100.0 \\
\hline
\end{tabular}

The use of candles comes with enormous risks. If not handled appropriately it could cause fire outbreaks resulting in the loss of life and property. For example, in a study on the incidence of domestic fire outbreaks in Ghana, Ayarkwa Danso and Adinyira (2010) found that candles are a major cause of domestic fires in the Accra, Tema and Kumasi metropolitan areas. Solar lamp and standby generators are the least used alternative power sources. These alternative power sources are expensive to buy, install and operate. Therefore, not many households, particularly in deprived communities in the Central Region, can afford to purchase and utilize them.

\section{Conclusions and Policy Implications}

This study sought to examine the factors that influence households' willingness to pay for reliable electricity services in Ghana. Akin to empirical studies in other countries, the findings of the present study revealed that though socioeconomic characteristics can be used to profile domestic electricity subscribers, they are different in terms of the nature of their influence on willingness to pay for reliable electricity services. For instance, while we found that marital status, level of education, household income and household size significantly affect willingness to pay, evidence of the significance of age and sex has not been validated. Thus, we can conclude that for Ghana age and gender does not matter in terms of valuing reliable electricity services compared to the other variables, especially level of education, monthly income and meter ownership status which 
are all significant at 1 percent. On the whole, the study indicates that most households are prepared to pay 44 percent $(\mathrm{GH} \phi 6.8)$ more, relative to the mean monthly electricity bill in the sample, to improve electricity services. This can be applied by regulators to adjust user tariffs so as to sustain electricity generation and distribution. The findings of the study also offer a number of policy implications for the electricity sector. Of utmost importance is improving access to separate electricity meters by residential users. As much as practicable, all regional and zonal offices of the Electricity Company of Ghana should simplify the meter application process for residential consumers and reduce the waiting time. This will make it possible for many households to have their own meters. Moreover, key actors responsible for retailing and recovering payment for electricity, namely Electricity Company of Ghana and private vendors and their employees, need to engage with the public in an open and transparent manner and ensure that information on power outages is effectively and timely communicated to consumers. Removing inefficiencies at all levels in the energy sector could improve the satisfaction of residential users and increase their willingness to support upward tariff adjustment. Furthermore, creating a congenial atmosphere for the expansion of commercial activities could improve willingness to pay for reliable electricity services via increase in household income and economic status. To achieve this, it may be advisable for financial service provider to reduce interest rates on loans to small scale and medium entrepreneurs. Above all, public education on electricity conservation practices and safe handling of alternative sources of energy, such as candles and lanterns, during power outages is strongly advocated.

Methodologically, the study has made a number of significant contributions to the discourse on the determinants of willingness to pay for quality electricity services. First, unlike other studies which exclude outliers and zero bids prior to estimating the willingness to pay functions, this study applied the tobit regression technique which takes all these bids into consideration. By including extremely large bids as well as zero bids, and using more econometrically robust estimation technique, the study provides more reliable results that can inform policy in a better fashion than otherwise. Another novel contribution of the study is that it used a two-stage sampling procedure thus overcoming the interviewer-interviewee relationship bias and the strategic response bias that are regularly reported in the literature. Moreover, this study is one of its first kind in Ghana which, in addition to examining the determinants of willingness to pay for reliable electricity services, also examined the reasons why some respondents were not willing to pay. That being said, a 
number of limitations associated with the study and direction for future research are worth highlighting. A major limitation of the study is that it is based on a rather limited sample and hence its findings may not be representative of the entire country due to the differences in economic circumstances and importance attached to reliable electricity supply. We suspect that differences in geographical location and the purpose for which different households demand electricity can affect their reaction to power outages and or willingness to pay for electric service reliability. Secondly, the study did not take attitudes and value orientation of the respondents into consideration though literature points to the fact that value orientation and political action attitudes can affect peoples' willingness to pay for public goods and services. Further, the study did not differentiate between the types of power outages that would be avoided as a result of the improvement in electricity supply. If respondent know the kinds of power outage that they can prevent, it can influence their willingness to pay. Future researchers can test the influence of value orientation and political party affiliation on willingness to pay for reliable electricity services and extent the scope by using a more nationally representative sample than one metropolitan area. They can also investigate specific types of power outages that household can tolerate and those that they are willing to pay to avoid. It would also be a novel contribution for future studies to examine whether there are significant variations in willingness to pay for reliable electricity services across urban and rural locations.

\section{Acknowledgements}

We are grateful to Wisdom Takuma and William Mensah for assisting us with the data collection, and four anonymous people for their comments.

\section{References}

Abdullah, S., \& Jeanty, W. P. (2011). Willingness to pay for renewable energy: Evidence from a contingent valuation survey in Kenya. Renewable and Sustainable Energy Reviews, 15, 29742983.

Abdullah, S., \& Mariel, P. (2010). Choice experiment study on the willingness to pay to improve electricity services. Energy Policy, 38(8), 4570-4581. 
Ahiakpor, F., Alnaa, S. E., \& Aglobitse, P. B. (2011). Willingness to pay for efficient waste management: The case of Bolgatanga Municipality. Oguaa Journal of Social Sciences, 6(1), 170189.

Ajzen, I., Brown, T. C., \& Rosenthal, L. H. (1996). Information bias in contingent valuation: Effects of personal relevance, quality of information, and motivation orientation. Journal of Environmental Economics and Management, 30, 43-57.

Akcura, E. (2011). Information effects in valuation of electricity and water service attributes using contingent valuation. Cambridge Working Paper in Economics 1156 \& Electricity Research Policy Group Working Paper 1127. University of Cambridge.

Amador, F. J., González, R. M., \& Ramos-Real, F. J. (2012). Supplier choice and WTP for electricity attributes in an emerging market: The role of past experience, environmental concern and energy saving behaviour. Documento De Trabajo/Working Paper Serie Economía, DT-E2012-03. Universidad De La Laguna.

Ameniya, T. (1973). Regression analysis when the dependent variable is truncated normal. Econometrica, 41, 997-1016.

Andreoni, J. (1990). Impure altruism and donations to public goods: A theory of warm-glow giving. The Economic Journal, 100(401), 464-477.

Aravena-Novielli, C., Hutchinson, G. W. \& Longo, A. (2012). Environmental pricing of externalities from different sources of electricity generation in Chile. Energy Economics, 34(4), 1214-1225.

Asante, B. K. (2013). The economy is not healthy: Whose fault? Accra: Daily Graphic. Issue No. 19214. July 29, 2013. P. 7.

Ayarkwa, J., Danso, A. K., \& Adinyira, E. (2010). Incidence of domestic fire outbreaks in Ghana: Causes and prevention. The Ghana Surveyor, 3(1), 7-20.

Baidoo, I., Al-Hassan, R. M., Asuming-Brempong, S., Osei-Akoto, I., \& Asante, F. A. (2013). Willingness to pay for improved water for farming in the Upper East Region of Ghana. Greener Journal of Agricultural Sciences, 3(4), 271-279.

Bergstrom, J. C., Stoll, J. R., \& Randall, A. (1989). Information effects in contingent markets. American Journal of Agricultural Economics, 71(3), 686-691.

Bigerna, S., \& Polinori, P. (2011). Italian consumers' willingness to pay for renewable Energy Sources. MPRA Paper No. 34408.

Boohene, R., \& Peprah, J. A. (2012). Correlates of revenue among small scale women fish processors in coastal Ghana. Journal of Sustainable Development, 5(10), 1-12. 
Bowen, R. H. (1943). The interpretation of voting in the allocation of economic resources. Quarterly Journal of Economics, 58, 27-48.

Boyle, K. (1989). Commodity valuation and the specification of contingent valuation questions. Land Economics, 65, 57-63.

Cape Coast Metropolitan Assembly (2009). Annual progress report. Cape Coast: Cape Coast Metropolitan Assembly.

Carlsson, F., \& Martinsson, P. (2007). Willingness to pay among Swedish households to avoid power outages - A random parameter Tobit model approach. The Energy Journal, 28(1), 75-89.

Carlsson, F., \& Martinsson, P. (2008). Does it matter when a power outage occurs?-A choice experiment study on the willingness to pay to avoid power outages. Energy Economics, 30(3), 1232-1245.

Carlsson, F., Martinsson, P., \& Akay, A. (2009). The effect of power outages and cheap talk on willingness to pay to reduce outages. IZA Discussion Paper Series No. 4307. Institute for the Study of Labor. Bonn.

Carson, R. T., Flores, N. E., \& Meade, N. F. (2001). Contingent valuation: Controversies and evidence. Environmental and Resource Economics, 19, 173-210.

Ciriacy-Wantrup, V. S. (1947). Capital returns from soil-conservation practices. Journal of Farm Economics, 29, 1181-1196.

Claudy, M. C., Peterson, M., \& O’Driscoll, A. (2012). “I like it, but I won't buy it”: Exploring the attitude-behaviour gap for renewable energy adoption. Papers of the $37^{\text {th }}$ Annual Macromarketing Conference, Berlin, June 13 - 16, 2012, Pp. 324-345.

du Preez, M., Menzies, G., Sale, M., \& Hosking, S. (2012). Measuring the indirect costs associated with the establishment of a wind farm: An Application of the contingent valuation method. Journal of Energy in Southern Africa, 23(1), 1-7.

Dupont, D. \& Bateman, I. J. (2012). Political affiliation and willingness to pay: An examination of the nature of benefits and means of provision. Ecological Economics, 75, 43-51.

Edjekumhene, I., \& Cobson-Cobbold, J. C. (2011). Low-carbon Africa: Ghana. London: Christian Aid.

Edkins, T. M. (2008). The South African case for concentrated solar thermal power: Assessing the contribution of CER and TREC financing. Unpublished Master's Thesis. Oxford University.

Energy Commission (2006). Strategic national energy plan 2006-2020. Accra: Energy Commission. 
Energy Commission (2013). 2013 energy outlook for Ghana. Accra: Energy Commission.

Ghana Statistical Service (2013). 2010 population \& housing census regional analytical report: Central Region. Accra: Ghana Statistical Service.

Goett, A. A., Hudson, K., \& Train, K. E. (2000). Customer's choice among retail energy suppliers: The willingness-to-pay for service attributes. The Energy Journal, 21(4), 1-28.

Greene, W.H. (2003). Econometric analysis. ${ }^{\text {th }}$ Ed. New Jersey: Pearson Education Inc.

Gunatilake, H., Maddipati, N. \& Patail, S. (2012). Willingness to pay for good quality uninterrupted power supply in Madhya Pradesh, India. Asian Development Bank Working Paper Series No.13. Asian Development Bank. Manila.

Haab, C. T. \& McConnell, K. E. (2002). Valuing environmental and natural resources: The econometrics of non-market valuation. London: Elgar Publishing Ltd.

Hansla, A. (2011). Value orientation and framing as determinants of stated willingness to pay for eco-labeled electricity. Energy Efficiency, 4(2), 304-318.

Hausman, A. J. (2012). Contingent valuation: from dubious to hopeless. Journal of Economic Perspectives, 26(4), 43-56.

Hobman, E. V., \& Frederiks, E. R. (2014). Barriers to green electricity subscription in Australia:"Love the environment, love renewable energy... but why should I pay more?". Energy Research \& Social Science, 3, 78-88.

Hoevenagel, R., \& van der Linden, J. W. (1993). Different descriptions of the ecological good on willingness to pay values. Ecological Economics, 7(3), 223-238.

Hoyos, D., \& Mariel, P. (2010). Contingent valuation: Past, present and future. Prague Economic Papers, 4, 329-343.

Institute of Economic Affairs (2007). Annual economic review and outlook: 2006. Accra: Institute of Economic Affairs.

Institute of Statistical, Social and Economic Research (2005). Guide to electric power in Ghana. Accra: Institute of Statistical, Social and Economic Research.

Kagel, J. H., Harstad, R. M., \& Levin, D. (1987). Information impact and allocation rules in auctions with affiliated private values: A laboratory study. Econometrica, 55(6), 1275-1308.

Kahneman, D., \& Knetsch, J. (1992). Valuing public goods: The purchase of moral satisfaction. Journal of Environmental Economics and Management, 22(1), 57-70. 
Kotchen, M. J., \& Moore, M. R. (2007). Private provision of environmental public goods: Household participation in green-electricity programs. Journal of Environmental Economics and Management, 53(1), 1-16.

Kuunibe, N., Issahaku, H., \& Nkegbe, P. K. (2013). Wood based biomass fuel consumption in the Upper West Region of Ghana: Implications for environmental sustainability. Journal of Sustainable Development Studies, 3(2), 181-198.

Louw, K., Conradie, B., Howells, M., \& Dekenah, M. (2008). Determinants of electricity demand for newly electrified low-income African households. Energy Policy, 36(8), 2814-2820.

Mariwah, S., Kendie, S. B., \& Dei, A. L. (2010). Residents' perception of the solid waste problem in the Shama-Ahanta-East Metropolitan Area, Ghana. Oguaa Journal of Social Sciences, 5(1), 2143.

Martinez-Paz, M. J., Almansa-Sáez, C., \& Perni-Llorente, Á. (2011). Energía eléctrica procedente de fuentes renovables: Percepción social y disposición al pago. Estudios de economía aplicada, $29(2), 539-560$.

Maslow, A. (1943). A theory of human motivation. Psychological Review, 50(4), 370-396.

McDonald, J. F., \& Moffitt, R. A. (1980). The use of Tobit analysis. The Review of Economics and Statistics, 62, 318-321.

Mitchell, C. R., \& Carson, R. T. (1989). Using surveys to value public goods: The contingent valuation method. Baltimore: John Hopkins University Press.

Muzenda, D. (2009). Increasing private investment in African energy infrastructure. Ministerial and Expert Roundtable, NEPAD-OECD Africa Investment Initiative.

Nemb, P. S., \& Yah, N. C. (2010). The effects of information in contingent markets for environmental goods: Illustration from the Dja Forest Park in Cameroon. Journal of Sustainable Development in Africa, 12(6), 365-382.

Nessim, H., \& Dodge, R. (1995). Pricing: Policies and procedures. London: MacMillan Press.

Otegbulu, C. A. (2011). A contingent valuation model for assessing electricity demand. Journal of Financial Management of Property and Construction, 16(2), 126 - 146.

Oteng- Adjei, J. (2012). The oil and gas year: Ghana 2011- The year in review. The Who's Who of the Global Energy Industry Interview.

Pepermans, G. (2011). Do Flemish households value renewables? HUB Research Paper 2011/05.

Quartey, D. J. (2011). The demand for energy and economic welfare in Ghana. A Paper presented at the International Conference on Energy and People: Futures, Complexity and Challenges, Lady Margaret Hall, University of Oxford, Oxford, 20-21 September, 2011. 
Rowlands, I. H., Scott, D., \& Parker, P. (2003). Consumers and green electricity: Profiling potential purchasers. Business Strategy and the Environment, 12(1), 36-48.

Scarpa, R., \& Willis, K. (2010). Willingness-to-pay for renewable energy: Primary and discretionary choice of British households' for micro-generation technologies. Energy Economics, 32, 129-136.

Scholderer, J., Balderjahn, I., Bredahl, L., \& Grunert, K. G. (1999). The perceived risks and benefits of genetically modified food products: Experts versus consumers In E - European Advances in Consumer Research Volume 4, eds. Bernard Dubois, Tina M. Lowrey, and L. J. Shrum, Marc Vanhuele, Provo, UT : Association for Consumer Research, pp. 123-129.

Shi, L., Zhou, W., \& Kristrom, B. (2013). Residential demand for green electricity. Environmental Economics, 4(1), 51-62.

Streeten, P., Burki, S. J., ul Haq, M., Hicks, N., \& Stewart, F. (1981). First things first: Meeting basic human needs in the developing countries. New York: Oxford University Press.

Tobin, J. (1958). Estimation of relationships for limited dependent variables. Econometrica, 26, 24-36.

United Nations (2011). State of the world population 2011: People and possibilities in a world of 7 billion. New York: United Nations.

Vondolia, G. K. (2009). Do Ghanaian farmers have preferences for the national biodiversity strategy? A case study of farmers living around the Kakum National Park in the Central Region. Ghana Policy Journal, 3, 48-68.

Whitehead, J. C., \& Blomquist, G. C. (2008). Measuring contingent values for wetlands: Effects of information about related environmental goods. Water Resources Research, 27(10), 2523-2531.

Whittington, D. (2004). Ethical issues with contingent valuation surveys in developing countries: A note on informed consent and other concerns. Environmental and Resource Economics, 28, 507515.

Wiser, H. R. (2007). Using contingent valuation to explore willingness to pay for renewable energy: A comparison of collective and voluntary payment vehicles. Ecological Economics, 62(4), 419-432.

World Bank. (2003). World Development Report 2004: Making services work for poor people. Washington: World Bank.

Zoric, J., \& Hrovatin, N., (2012). Household willingness to pay for green electricity in Slovenia. Energy Policy, 47, 180-187. 